\title{
Parents - children awareness and knowledge of the Child Rights Act and its effect on the children in Nigeria
}

\author{
Lawal Oluwaseun Temitope ${ }^{l} \&$ Ajayi, Hannah Olubunmi ${ }^{1}$ \\ 1- Institute of Education, Obafemi Awolowo University, Ile - Ife, Nigeria. \\ Corresponding author contact: lordofhost2013@gmail.com
}

\begin{abstract}
The present paper explores the level of awareness and knowledge of both the parents and their children as to the Child's Rights Act and assesses the level of and differences in its implementation by ethnicity. The study employs a survey research design and a population of parents from the major three ethnic groups (Hausa, Igbo, and Yoruba) residing in Ibadan, Oyo State, Nigeria. Preferred, for the purposes of the proposed paper, is the multi-stage sampling procedure and a sample size of 120 parents and 120 children. Two self-designed survey instruments were administered in the process of inquiry; three research questions were answered and one hypothesis tested. The data obtained were analyzed using frequency count, percentage, and One- Way ANOVA. The results show that (51.7\%) of the parents and (53.3\%) of the children are well aware of the Child's Rights Act with $76.7 \%$ of the parents having a high level of knowledge on the Rights of the Child. The results also show that there is a significant difference between the parental level of awareness and knowledge based on their belonging to various tribes at 0.05 significant level $(p<0.5)$. The findings provide further information on some aspects of the child's rights that parents need to pay more attention to and ensure their children the rights they deserve.
\end{abstract}

Key Words: Parental Awareness, Knowledge, Child Rights Act, Children Awareness, Ethnic Groups

\section{Introduction}

The child is the bedrock and sustaining pillar of any society, if there would be continuity of human society at all, children are the greatest assurance for it. The implication is, children stand for the sustainability of human society. Therefore, to have a future that is sustainable, today's children should be given the consideration and attention they deserve and that would be done in recognition of their rights as well as affording them as much protection as possible. Where children rights are established and they feel protected, then there is the assurance that children would thrive better in such a situation or society. UNICEF (2013) stated that giving recognition to children's rights is to prevent them from harm and to actively safeguard the best interests of children. However, children all over the world experience numerous challenges that pose threats to their survival and thriving, which, accordingly, was the underlying reason for the United Nations to take a giant stride in articulating the rights of children. Thus, adopted, on the 20th November 1989, was the Convention on the Rights of the Child (CRC) by 189 heads of countries in Jomtien, Thailand. The Organization of African Union (OAU) Assembly of Heads of States and Governments came up with the African Union Charter of the document known as, African Charter on the Rights and Welfare of the Child (ACRWC) in 1990 at Addis Ababa, Ethiopia. In 1991 and 2000 respectively, Nigeria adopted the two documents making them binding and legal documents for implementation in the country. The universal standards and principles in the documents are survival, development, protection and children participation in issues that have to do with their development. The broader implication of these documents is that children are human beings and have their own rights which must be granted to them by virtue and they must be protected by rule of law. To that end, the documents provide a clear definition of a child as 'every human being under the age of 18 years' and their rights must be given adequate recognition.

In 2003, Nigeria moved a step further to domesticate the document and referred to it as Child Rights Act (FGN,2003) to provide a legislation which incorporates all the rights and responsibilities of the children, and to specify the duties and obligations of the government, parents and other authorities or bodies to specify what the rights stipulate in the document. Listing through the contents of the United 
Nations Convention on the Rights of the Child (UNCRC), OAU Charter and Child's Rights Act 2003 (CRA), found is little difference, which is to indicate that at the global, regional and national level, the child is highly esteemed and whatever is in the best interests of the child shall remain paramount to all the spheres of the system. Therefore, the child, irrespective of its sex, ethnicity, religion or even disability should be given adequate protection and care to maintain its wellbeing, and must be accorded the right to survival and development, and to a name and registration at birth as stipulated in all the documents. Pathetically, out of the thirty-six states in Nigeria at present, only 26 states have ratified, adopted or domesticated the Act. The remaining ten states have not, for the reasons best known to them, which is against the children's best interests. Even in the states that have domesticated the Act, implementation and enforcement of the content is still not encouraging. The evidence of different types of abuse of varying degrees, neglect and other forms of violence against children pervade the country (Falae, 2018; Edeh, 2017; Eze, 2013). It has been identified that the lack of knowledge or awareness about the issue especially on the part of the parents has been militating against the implementation and enforcement of the Act. If parents do not have the adequate knowledge of what is required of them in upholding the rights of children and their own responsibility as stipulated in the Act, it might be difficult to prosecute anybody. It is therefore, imperative to state that one's knowledge and awareness about a given issue or concept would in no measure influence what would be their attitude to that issue as well as how one would behave or act in accordance with it. Little wonder that children receive different forms of treatment from the society. Olumodeji (2008) indicated that the society should, out of necessity, give serious consideration to the welfare of every child because once the needs of the child are met at the appropriate time, it will influence all the aspects of their development and the general well-being of the society as a whole.

Unfortunately, in many societies like Nigeria, children have often been neglected with their welfare being trampled upon. In the light of this, it was Akwara, Soyibo, and Agba (2010) who gave prominence to the fact that the rights of the child have not been respected in Nigeria. In such a situation, the development of the society will be catastrophic not a sustainable one, or more precisely, if drastic actions are not taken to review the present situation, the social catastrophe is inevitable. The scholars, therefore mindful of the findings, emphasized that careful attention needs to be focused on this issue if children are truly taken as the future of any nation. Njoku and Oladiji (2009), after identifying the enormity of the challenges the children in the 21st century face, urged for serious action on the propagation and implementation of the Child Rights Act in all the regions of the country. Furthermore, Akor (2009) reported that in many parts of the Nigerian society, children are subjected to several dehumanizing conditions when they, for example, are caught street hawking, though some parents, according to the findings, are of the opinion that the efforts of the children were to augment the family income. This view may be an indication that the parents are not aware that such act is against the grain of the Child Rights Act (Law) and there are penalties attached to it. Even other rights, such as the rights to quality health care, clean drinking water and safe sanitation environment, the right to life, a name and education, have not yet been accorded to considerable amount of the children in the country. In spite of the fact that these rights statements and the other documents advocating the rights of the children in Nigeria are legally binding, , still, there is a large number of the children that are out of school, hawking about on the streets when they are expected to be at school, or other children who do not have access to health care services, and innumerable number of children who experience one sort of abuse or another on a daily basis, ranging from assault, rape to other forms of violence. It is hard to open the pages of the You cannot read the Dailies or listen to the News without hearing the reports of one form of abuse or maltreatment against the children. One therefore wonders if people, especially parents, really are aware of the children's rights act in Nigeria. It is expected that having adequate knowledge and awareness about the rights accorded to the children would improve the quality of life of the children and the society as a whole. The knowledge and awareness are expected to begin with parents themselves who serve as primary caregivers for their children. It is therefore needful to examine this aspect just as Covell and Rowe (1999) have pointed out that people, especially parents should be well-informed about the rights of the children, not basically for legal reasons but to increase people' positive attitude to these rights. This implies that adequate knowledge and awareness of something (in the case, the rights that are accorded to the children) is likely to produce a positive attitude towards the issue.

Nigeria as a heterogeneous nation has over 500 ethnic groups identified by their own traditional norms and values which influence the upbringing of the children. With some of the traditions already 
identified as being detrimental to the implementation of the rights that should be granted to the children irrespective of ethnicity or gender, parents' awareness and knowledge of the rights towards their children would be of utmost importance. The largest prominent ethnic groups are the Hausa, Igbo and Yoruba. Parents from these tribes have their traditional and personal ways of nurturing their children which may have similarities or differences, and when related to the Child's Right Act, might be at variance with the expectations to the child. However, moving from one's state of origin to reside in another state may influence either positively or negatively one's outlook to life and issues including their cultural ideology, hence, there could be acculturation and it may also influence children's upbringing. When parents get involved in the implementation of the rights accorded to the children, then the children will be provided with ample opportunities to thrive and have a better future, and even the society also would benefit positively from such a practice. If otherwise, the cycle might continue from one generation to another, with the abused becoming the abuser, as the saying goes. In such a context, there might not be a sustainable society.

\subsection{Statement of the Problem}

In spite of the Federal Government commitment towards the Child Rights Act in Nigeria that led to the legal framework formulation (2003), its implementation, however, has not been properly addressed or more precisely, turned out to be ineffective and inefficient (Obokoh, 2019). Applying the children's rights, in terms of survival, development, protection and participation are nothing to write home about. Children in different parts of Nigeria are experiencing various forms of violence and abuse more or less on a daily basis. It is almost impossible to open the pages of the dailies or listen to the news on either the radio or television without running into one form of abuse against children or another (Segun - Bello, 2018; Oladiji, 2019). As children are reported of being raped, kidnapped, brutalized or being neglected in these media so also many of them are seen either hawking or begging around the streets whereas, myriads of them are supposed to be at school (Moore, 2014; Folayan, Odetoyinbo, Harrison, \& Brown, 2014; Edeh, 2017). The implication is that many of the rights spelt out in the Child Rights Act are being violated by those who are expected to uphold them. If people, especially parents and children, are aware and have adequate knowledge of these rights, probably the violation might not be as intense as it is. To allow the situation to continue would amount to non-realization of a more promising future for the children under consideration and the society at large. Hence, this study strives to examine the issue of the level of awareness and knowledge about the Child's Rights Act in Nigeria from the perspectives of both the children and their parents, especially in Oyo State, and it is not certain whether the state of residence would influence the other ethnic groups (Igbo and Hausa) residing in that State. To carry out the study, the following objectives were therefore set as follows:

\subsection{Objectives:}

i. investigate the parents' awareness and knowledge on the Child's Right Act in Oyo State

ii. determine the level of children's awareness on their legal rights as children in the area under study.

iii. examine the level of implementation of the Child's Rights by the parents in the area under investigation.

iv. assess the difference in the parental levels of awareness and knowledge of the Child Rights based on ethnicity. 


\subsection{Research questions}

i. a. Are the parents in Oyo State aware of the Child Rights Act?

b. Do parents have the knowledge of some of their children rights in accordance with the Child Rights Act, 2003?

ii. What is the children's level of awareness of on some of their rights in accordance with the Child Rights Act?

iii. What is the level of implementation of some specific Child Rights by the parents?

\subsection{Hypotheses}

Ho1. There is no significant difference between the parental levels of awareness and knowledge on some children rights in accordance with the Child Rights Act based on ethnicity.

\section{Methodology}

Descriptive survey design was adopted for this study. The design entails the systematic collection and use of data from a given population to describe certain characteristic features of the population. The design is considered appropriate for this study because it allows the collection of data from small groups with a view to describe the entire population vis -a -vis determining the level of knowledge and awareness of both the parents and their children on the Child Rights Act and its application in the earliest years of the child development. The population comprised all the children in their early childhood years and their parents from the three major tribes in Nigeria residing in the Southwestern part of Nigeria. The sample size consisted of one hundred and twenty (120) children who were randomly selected using simple random sampling technique from the three major tribes consisting of 40 children from each tribe, and one hundred and twenty (120) parents who were purposively selected because their children had originally been selected. One state from the six southwestern states was selected using random sampling technique and a multi-ethnic urban/metropolitan location in the Southwest, Nigeria was selected using random sampling technique.

A two self- designed instruments entitled, 'Parents' Awareness and Knowledge of Child Rights Act Questionnaire' (PAKCRAQ) and 'Children's Awareness and Knowledge of the Child Rights Act Questionnaire' (CAKCRAQ) were used for the study. The instruments were made up of two sections. Section A and section B. Section A contained item eliciting the biodata of the participants. Section B contained 20 items for each of the parents and the children, with item 1 of each of the questionnaires processing the awareness of both the parents and the children on the Child Rights Act. Items 2-10 of parents' questionnaire investigated the parents' impression on the Child Rights Act. Items 11-20 assessed the parents' knowledge about their children rights in accordance with the Child Rights Act 2003. In children's questionnaire the items 2-4 investigated the rights to fair hearing, 5-6 focused on the right to birth registration, 7 on the right to education, 8-10 dealt with the right to parental care, protection and maintenance, 11 considered the right to survival and development, 12-13 and 15-20 assessed the child's right against discrimination and item 14 assessed the rights to a name.

Children's questionnaire was administered to them in the form of an interview with the researchers interacting with the children in their local languages where necessary for those of them who could not speak English, and their responses to the items stated above were recorded, transcribed and coded. The collected data was subsequently analyzed using percentage, mean and One-Way Analysis of Variance. 


\section{Results}

3.1. Research Question 1a. Are the parents in Oyo State aware of the Child Rights Act?

Table 1. Frequency and Percentage Count Showing Parent's Awareness of the Child Rights Act.

\begin{tabular}{|c|c|c|}
\hline $\begin{array}{l}\text { Level of Parent's Awareness } \\
\text { of the Child Rights Act. }\end{array}$ & Frequency (f) & Percentage \% \\
\hline AWARE & 62 & $51.7 \%$ \\
\hline UNAWARE & 58 & $48.3 \%$ \\
\hline Total & 120 & 100.0 \\
\hline
\end{tabular}

The results from table 1 show that $62(51.7 \%)$ of the parents are aware of the Child Rights Act, while $58(48.3 \%)$ are not aware of these rights.

1b. Do parents have the required knowledge of some of their children rights in accordance with the Child Rights Act, 2003?

Table 2. Frequency, Mean and Percentage Count Showing the Parent's Knowledge of some of their children rights in accordance with the Child Rights Act.

\begin{tabular}{|l|c|c|c|c|}
\hline \multicolumn{1}{|c|}{ Parents' Knowledge of some Child's Rights } & Frequency (f) & Percentage (\%) & Mean & Level \\
\hline Children's right to fair hearing & 108 & 90 & 1.72 & High \\
\hline Children's right to registration of birth & 114 & 95 & 1.78 & High \\
\hline Children's right to education & 116 & 96.6 & 1.80 & High \\
\hline $\begin{array}{l}\text { Children's right to parental care, protection as } \\
\text { well as maintenance. }\end{array}$ & 108 & 90 & 1.72 & High \\
\hline Children's right to survival and development & 118 & 98.3 & 1.80 & High \\
\hline Children's right against discrimination. & 106 & 88.3 & 1.71 & High \\
\hline Children's right to gender equality in education & 116 & 96.6 & 1.80 & High \\
\hline
\end{tabular}

Range: $0-45=$ Low; $46-60=$ Moderate; $61-90=$ High

Table 2 shows the levels of parents' knowledge as to some of their children's rights in accordance with the Child Rights Act 2003. It can be observed that the majority of the parents had high level of knowledge of some of their children's rights- $108(90 \%, \mathrm{M}=1.72)$ were well aware of the right to fair hearing, $114(95 \%, \mathrm{M}=1.78)$ - of the right to registration of birth, $116(96.6 \%, \mathrm{M}=1.80)$ - of the right to education, $108(90 \%, \mathrm{M}=1.72)$ - of the right to parental care, protection as well as maintenance, $118(98.3 \%, \mathrm{M}=1.805)$ - of the right to survival and development, $106(88.3 \%, \mathrm{M}=1.71)$ - of the right against discrimination and $116(96.6 \%, \mathrm{M}=1.80)$ - of the right to gender equality. It can be assumed from the above-stated results that the surveyed parents were not ignorant of their children's rights.

3.2 Research Question 2. What is the children's level of awareness on some of their rights in accordance with the Child Rights Act?

Table 3: Frequency, Mean and Percentage Count Showing the Children's Level of Awareness on some of their Rights.

\begin{tabular}{|l|c|c|c|c|}
\hline $\begin{array}{l}\text { Children's Level of Awareness about } \\
\text { some of their Rights }\end{array}$ & $\begin{array}{c}\text { Frequency } \\
(\mathbf{f})\end{array}$ & $\begin{array}{c}\text { Percentage } \\
(\boldsymbol{\%})\end{array}$ & Mean & Level \\
\hline Right to fair hearing & 98 & 81.6 & 1.91 & High \\
\hline Right to registration of birth & 66 & 55 & 2.00 & Moderate \\
\hline Right to education & 104 & 86.6 & 1.71 & High \\
\hline $\begin{array}{l}\text { Right to parental care, protection as well as } \\
\text { maintenance. }\end{array}$ & 92 & 76.6 & 1.97 & High \\
\hline Right to survival and development & 116 & 96.6 & 1.80 & High \\
\hline Right from discrimination. & 88 & 73.3 & 2.02 & High \\
\hline Right to a name & 116 & 96.6 & 1.80 & High \\
\hline
\end{tabular}

Range: 0 - 45 = Low; 46 - 60 = Moderate; 61 - $90=$ High 
Table 3 reveals that the highest percentage of the children are aware of some of their specific rights stated in the Child Rights Act. Namely, 98(81.6\%, M=1.91) were well aware of their right to fair hearing, $104(86.6 \%, \mathrm{M}=1.71)$ - of the right to education, $92(76.6 \%, \mathrm{M}=1.97)$ - of the right to parental care, protection as well as maintenance, $116(96.6 \%, \mathrm{M}=1.80)$ - of the right to survival and development, $88(73.3 \%, \mathrm{M}=2.02)$ - of the right against discrimination, $116(96.6 \%, \mathrm{M}=1.80)$ - of the right to a name, while $66(55 \%, M=2.00)$ children had a moderate level of awareness about the right to registration of birth.

3.3 Research Question 3: What is the parental level of implementation of the Child Rights

Table 4: Frequency, Percentage Count and Means Showing the parental level of implementation of Child Rights.

\begin{tabular}{|l|c|c|c|c|c|c|}
\hline \multicolumn{1}{|c|}{ Rights } & $\begin{array}{c}\text { Frequency } \\
\text { YES (f) }\end{array}$ & $\begin{array}{c}\text { Percentage } \\
\text { \% }\end{array}$ & $\begin{array}{c}\text { Frequency } \\
\text { NO (f) }\end{array}$ & $\begin{array}{c}\text { Percentage } \\
\text { \% }\end{array}$ & Mean & Ranking \\
\hline Right to fair hearing & 94 & $78.3 \%$ & 26 & $21.7 \%$ & 1.22 & 4 \\
\hline $\begin{array}{l}\text { Right to registration } \\
\text { of birth }\end{array}$ & 76 & $63.3 \%$ & 44 & $36.7 \%$ & 1.36 & 6 \\
\hline $\begin{array}{l}\text { Right to education } \\
\text { Right to parental care, } \\
\text { protection as well as } \\
\text { maintenance. }\end{array}$ & 104 & $86.7 \%$ & 16 & $13.3 \%$ & 1.13 & 2 \\
\hline $\begin{array}{l}\text { Right to survival and } \\
\text { development }\end{array}$ & 104 & $86.7 \%$ & 16 & $13.3 \%$ & 1.13 & 3 \\
\hline $\begin{array}{l}\text { Right against dis- } \\
\text { crimination. }\end{array}$ & 92 & $76.7 \%$ & 28 & $23.3 \%$ & 1.23 & 5 \\
\hline \begin{tabular}{l} 
Right to a name \\
\hline
\end{tabular} & 116 & $96.7 \%$ & 04 & $3.3 \%$ & 1.03 & 1 \\
\hline
\end{tabular}

Observed in table 4 presenting the percentages and means of the parental level of implementation of specific Child Rights parents , is that $116(96.7 \% \mathrm{M}=1.03)$ of the children are enjoying the right to a name, 104(86.7\%, $\mathrm{M}=1.13)$ - the right to survival and development, 104(86.7\%, $\mathrm{M}=1.13)$ - the right to education, $94(78.3 \%, \mathrm{M}=1.22)$ - the right to fair hearing, $92(76.7 \%, \mathrm{M}=1.23)$ - the right against discrimination, $76(63.3 \%, \mathrm{M}=1.36)$ - the right to birth registration, while $64(53.3 \%, \mathrm{M}=1.47)$ - the right to parental care, protection and maintenance.

Hol: There is no significant difference based on ethnicity between the parental level of awareness and knowledge on some children rights in accordance with the Child Rights Act.

Table 5 and 6. One Way ANOVA showing significant difference based on ethnicity in the parental level of awareness and knowledge on some children rights in accordance with the Child Rights Act.

\begin{tabular}{|l|c|c|c|c|c|}
\hline & $\begin{array}{c}\text { Sum of } \\
\text { Squares }\end{array}$ & df & Mean Square & F & Sig. \\
\hline Between Groups & 76.673 & 2 & 38.337 & 45.173 & 0.000 \\
\hline Within Groups & 99.293 & 117 & 0.849 & & \\
\hline Total & 175.967 & 119 & & & \\
\hline
\end{tabular}

Table 5 shows that, altogether, there is significant difference in the level of the parental knowledge and awareness irrespective of their tribes on some children rights in accordance with the Child Rights Act at the $\mathrm{p}<0.05$ level $\{\mathrm{F}(2,117)=45.2, \mathrm{p}=0.00\}$. Therefore, the null hypothesis is rejected. 
Table 6. Post hoc comparisons showing significant difference between the level of parental awareness and knowledge on some of the children's rights in accordance with the Child Rights Act based on their ethnicity.

\begin{tabular}{|c|c|c|c|c|c|c|c|c|}
\hline \multirow[t]{2}{*}{ TRIBES } & \multirow[t]{2}{*}{$\mathrm{N}$} & \multirow[t]{2}{*}{ Mean } & \multirow[t]{2}{*}{$\begin{array}{l}\text { Std. De- } \\
\text { viation }\end{array}$} & \multirow[t]{2}{*}{$\begin{array}{ll}\text { Std. Er- } \\
\text { ror }\end{array}$} & \multicolumn{2}{|c|}{\begin{tabular}{|c|}
$\begin{array}{c}95 \% \text { Confidence Inter- } \\
\text { val for Mean }\end{array}$ \\
\end{tabular}} & \multirow[t]{2}{*}{ Minimum } & \multirow[t]{2}{*}{$\begin{array}{c}\text { Maxi- } \\
\text { mum }\end{array}$} \\
\hline & & & & & $\begin{array}{l}\text { Lower } \\
\text { Bound }\end{array}$ & $\begin{array}{l}\text { Upper } \\
\text { Bound }\end{array}$ & & \\
\hline HAUSA & 53 & 3.6604 & 0.95964 & 0.13182 & 3.3959 & 3.9249 & 1.00 & 4.00 \\
\hline IGBO & 39 & 2.4615 & 0.75555 & 0.12098 & 2.2166 & 2.7065 & 2.00 & 4.00 \\
\hline YORUBA & 28 & 1.7143 & 1.04906 & .19825 & 1.3075 & 2.1211 & 1.00 & 4.00 \\
\hline Total & 120 & 2.8167 & 1.21602 & .11101 & 2.5969 & 3.0365 & 1.00 & 4.00 \\
\hline
\end{tabular}

Table 6 shows that there is significant difference in the level of Yoruba parents' awareness and knowledge with $(\mathrm{M}=1.80$, S.D. $=1.71)$ to that of Hausa parents $(\mathrm{M}=3.70$, S.D. $=0.95)$ and Igbo parents $(\mathrm{M}=2.50, \mathrm{~S} . \mathrm{D}=0.75)$ on some children rights, in accordance with the Child Rights Act, based on ethnicity at $0.05(\mathrm{p}<0.5)$ significant level while there is no significant difference between Hausa and Igbo parents.

\section{Discussion of Findings}

The findings of the study on level of awareness of both parents and children on the Child Right Act in Akinyele Local Government Area of Oyo State revealed that the highest percentage of parents and children are well aware of the Child Rights Act. The reason for this may be due to parents' personal or cultural dispositions to child rearing that made them embrace the Act, or their awareness of the Child Rights Act may be as a result of enlightenment through friends and media, while children might have been taught at school during their Civic Education Studies or Social Studies since the child rights issues are embedded in the school curriculum as preprimary class upwards. The finding is in line with Ojebiyi, Ashimolowo, Banmeke and Ariyo (2016) who discovered that a high percentage of the residents in Ogun State also have the awareness of the Child Rights Act with higher levels of awareness being distributed in the state's urban areas. However, it negated Oyero (2011) who found out that children, even at the secondary school level, in Lagos State were not aware of the United Nation Child Rights Convention in spite of the fact that the three States had domesticated the Acts, and therefore, they knew that children have some rights (Lagos State of Nigeria, 2008; Vanguard, 2017). The disparity in the awareness might be that the surrounding environment favored one group of children than the other in terms of population and intensity of advocacy campaign. The finding on parents' level of knowledge about the Child Rights indicated that parents had high level of knowledge of the Child Rights Act. This result is not in agreement with that of Okoye (2011) who revealed that parents in Enugu community have limited knowledge of the Child Rights Act just as it has been emphasized that it has received less acceptability in Enugu (UNUCEF, 2011).

The findings on the level of rights implementation on the part of the parents revealed that some of the fundamental rights investigated in this study are being implemented by parents except for the right to parental care, protection and maintenance that has the lowest percentage, which may be due to parental level of income, environment and exposure as it was discovered during the interview with the respective parents. This is in line with Nwosu, Nwakaego, Eseadi, Arinola, Abah \& Asogwa (2015) who found out that some rights did not receive close attention, hence, called for counselling program for the parents. The findings revealed that there was a significant difference between the level of parental awareness based on their various tribes, which may be on the grounds of the parents' exposure or socio-cultural background. It was additionally revealed that there was significant difference on the parental knowledge about the 
child's rights when combining the three tribes, with the outcome being more favourable to Yoruba than Igbo and Hausa. This might be as a result of quick response in the Southwestern states to domesticate the Act. The awareness and knowledge of the rights by the Hausa and Igbo tribes might be associated with the environmental impact of living in the State as some studies in the Northern part of the country have established little or no awareness of the rights (Braimah, 2014). It further corroborated Okoye (2011) who surprisingly found that parental awareness and knowledge about the Act in Nsukka University town was unduly low. Similarly, Nwosu, Nwakaego, Eseadi, Arinola, Abah \& Asogwa (2015) discovered that parents in Nsukka were vaguely aware of the children rights, which is an indication that they had limited knowledge of the Act. This implies that there is still a great deal of campaign needed on this issue if rights would be widely accepted in the country.

The study further revealed the rights of children that have not received adequate attention among parents such as the children's right to fair hearing (not in terms of law issues but being listened to), non- discrimination, registration of birth and care, protection and maintenance. This implies that children have not been enjoying fair hearing from their parents which may still be the influence of the African culture mentality of "children should be seen and not heard (Gill, 2013). The right of non-discrimination has not also been overcome as there is still disparity in the treatment of boys and girls, the situation varies from region to region in Nigeria. In the Northern part of Nigeria, which is predominantly Hausa, girl-child does not receive adequate treatment in terms of education, hence, Tyoakaa, Amaka and Nor (2014) indicated that there is gender inequality that placed the girl-child at a disadvantaged position in some other part of the country but in the South Eastern part of Nigeria, which is predominantly Igbo, it is the boy-child that is affected. This might be the reason for the scant attention on this right among the parents in this study. Another area where discrimination might have occurred relate to children with disabilities, as parents are still ashamed of the fact that they have children with special needs. Some of such children are still being denied the chance of education and are being treated with neglect. For instance, Muuya (2002) indicated that educating children with disabilities was of no significance in myriad places. As for the right that has to do with registration of birth, there are still parents that give birth to their children either at home or birth attendant homes (Osagie, 2014). This low birth registration rates in Nigeria have been attributed to a number of factors, such as lack of awareness of current legislation and of the importance of birth registration (UN, 2007). The right of care, protection and maintenance ranked last among the parental rights examined in this study area, which implies that the surveyed parents may not be given much praise in this aspect. Ademola, Iluma, Godspower, Peters, Evin, Opukiri, et.al. (2017) therefore stated that the levels of poverty and the poor socio-economic situation in the country resulted in the treatment of vulnerability administered to the children being increasingly exposed to it.

\section{Recommendations}

1. The Government ministries, agencies and NGOs should increase their awareness programmes by organizing different programmes for parents to sensitize and orient them more on the Child's Rights Act.

2. There should be more awareness through different forms of media such as radio jingles, flyers, posters billboard messages and the like focusing on the child rights issues, violation of child's right and its implication on children, family and the society at large.

3. The health officials can also help to enlighten parents on the aspect of child's right that deals with health issues during parent visits to hospitals throughout the antenatal or postnatal care.

4. The teachers that teach child rights- related subjects should lay more emphasis on it with respect to the children and also educate their parents during the P.T.A. meetings. 
5. There should be parent empowerment programmes arranged by the government to help alleviate poverty so that parents would be able to give the necessary care, protection and maintenance to their children.

\section{Conclusion}

The study concluded that on the average, parents and children in the study area have considerable awareness as well as the knowledge of the Child Right Act. However, it turns out that parents are more likely to implement some of the rights their children are accorded with while other rights, such as the right to parental care, protection and maintenance and the right to birth registration still require more parental attention for a more effective implementation.

\section{References}

Ademola, LA, Iluma, TR, Godspower, TS, Peters, ME, Evin, S, Opukiri, J et.al. (2017). Achievements and Implications of Care and Support Programme among Orphans and Vulnerable Children: A Systematic Evaluation of HAF II Project in Bayelsa State, Nigeria. Journal of Research in Humanities and Social Science, 5(2) $64-69$. https://.www.questjournals.org.

Akor G (2009). Nigeria: Child's Right Abuse- Product of Inefficient Leadership. Retrieved from http://allafrica.com/stories/200910201191.html.

Akwara AF, Soyibo AG \& Agba, MS (2010). Law and Children's Rights Protection: The Nexus for a Sustainable Development in Nigeria. Canadian Social Science. 6(2), 26-33.

Braimah, TS (2014). Child marriage in Northern Nigeria: Section 61 of Part I of the 1999 Constitution and the protection of children against child marriage. African Human Rights Law Journal, 14 Ahrlj 474-48 8. https://doi.org/10.2139/ssrn.2309374

Covell K \& Howe RB (1999). The impact of children's rights education: A Canadian Study. Int. J.Children's Rights. 7:171-183. https://doi.org/10.1163/15718189920494327

Edeh, S (2017). Child Abuse Prevalent in all Nigeria's 36 States - UNICEF. https://www.vanguardngr.com/2017/05/.

Eze, UO (2013). Prevention of Sexual Assault in Nigeria. Annals of Ibadan Postgraduate Medicine, 11 (2), $65-70$.

Falae, V (2018). Violence against children in Nigeria: how to protect our kids? https://www.legit.ng/1128721-violence-children-nigeria-protect-kids.html

Federal Government of Nigeria (FGN2003). A bill for an act to provide and protect the right of the Nigerian child and other related matters, 2003.

Folayan, M. O., Odetoyinbo, M., Harrison, A. \& Brown, B. (2014). Rape in Nigeria: a silent epidemic among adolescents with implications for HIV infection. Global Health Action. 7 https://doi.org/10.3402/gha.v7.25583 
Gill, V (1996). Children Should be Seen and not Heard: The Production and Transgression of Adults' Public Space. Journal Urban Geography, 17(3), 205 - 220, Published online: 15 May 2013. https://doi.org/10.2747/0272-3638.17.3.205

Lagos State of Nigeria (2008). Child's Rights Law 2007. Lagos State of Nigeria Official Gazette Extraordinary No. 22, Vol. 41 of 25th March 2008.

Moore, J. (2014). Nigeria Prepares to Treat Rape, Sexual Trauma of Kidnapped School Girls. BuzzFeed News World Correspondent, May 29, 2014. https://www.buzzfeednews.com/article/jinamoore/nigeria-prepares-to-treat-rape-sexual-trauma-of-kidnapped-sc.

Muuya, J (2002). Aim of special education. European Journal of Special Needs Education, 17(3), 229-239. https://doi.org/10.1080/08856250210162130

Njoku G \& Oladiji S (2009). Calling on 15 states left to protect their children. THIS DAY: Retrieved from http://allafrica.com/stories/200911240582.html

Nwosu, EN, Nwakaego, IA, Eseadi, C, Arinola, AH, Abah, JI \& Asogwa, DE (2015). Counseling Needs of Parents for Increased Awareness of Child's Rights Act in Nigeria. Buletin Teknol. Tanaman,12, 249 - 253.

Obokoh, A. (2019). Nigeria's Child Rights Act implementation less than 20\%. Business Day Nigeria. November 21, https://businessday.ng/news/article/nigerias-child-rights-act-implementation-less-than-20.

Ojebiyi, WG, Ashimolowo, OR., Banmeke, TOA., \& Ariyo, AM (2016). Societal awareness of the child rights act among rural and urban dwellers in Ogun State. Journal of Humanities, Social Science and Creative Arts, 11 (1 \& 2), 14 - 25.

Okoye, U. O. (2011). Knowledge and awareness of the child's rights act among residents of a university town in Enugu State, Nigeria. Education Research, 2(10), 1591 - 1601. http://www.interesjournals.org/ER.

Oladiji, S. (2019). UNICEF challenge families on implementation of Child Rights Act. PM News, Friday, May 17, 2019. https://www.pmnewsnigeria.com/2019/05/17/unicef-challenge-families-on-implementation-of-child-rights-act.

Olumodeji,EO (2008). Theoretical Issues in Child's Rights. Department of Sociology, University of Jos, Jos, Nigeria.

Osagie, E (2014). UNICEF: Birth registration is right of every child. The Nation. https://thenationonlineng.net/unicef-birth-registration-is-right-of-every-child..

Oyero, O. (2011). Information sources and awareness of level of child rights in Lagos State, Nigeria. The Communication Review. 5(1), 86 -118. 
Segun - Bello, M. (2018). Child Rights Act: Magistrate Urges Nigerians to Develop will for Implementation. The Vanguard. February 19, 2018. https://www.vanguardngr.com/2018/02/child-rights-act-magistrate-urges-nigerians-develop-will-implementation.

Tyoakaa, LM, Amaka, JI \& Nor, A (2014). Problems and Challenges of Girl-Child Education in Nigeria: The Situation of Kalgo Local Government Area (L.G.A) of Kebbi State.

Journal of Research \& Method in Education, 4(4), 1 - 5. www.iosrjournals.com. https://doi.org/10.9790/7388-04440105

United Nations (UN). July 2007. United Nations Children's Fund (UNICEF) in Nigeria.

"Information Sheet: Birth Registration." [Accessed 15 May 2019]

UNICEF (2011). UNICEF Nigeria - Fact Sheet: Child Rights legislation in Nigeria.

UNICEF (2013). Children's Rights in Impact Assessments: A Guide for Integrating Children's Rights into Impact Assessments and Taking Action for Children. The Danish Institute for Human Rights. Copenhagen.

Vanguard News (2017). Oyo women lawyers hail State's child rights law, want enforcement. https://www.vanguardngr.com. 